\title{
Assessment of Undiscovered Resources in Calcrete Uranium Deposits, Southern High Plains Region of Texas, New Mexico, and Oklahoma, 2017
}

The U.S. Geological Survey estimates a mean of $\mathbf{4 0}$ million pounds of in-place uranium oxide $\left(\mathrm{U}_{3} \mathrm{O}_{8}\right)$ remaining as potential undiscovered resources in the Southern High Plains region of Texas, New Mexico, and Oklahoma. This estimate used a geology-based assessment method specific to calcrete uranium deposits.

\section{Introduction}

The United States is the world's largest consumer of uranium used in nuclear power plants, which provide approximately 19 percent of the Nation's electricity. Substantial uranium resources are identified in the United States, yet only 11 percent of uranium purchased by civilian nuclear power reactors during 2016 was obtained from domestic sources (U.S. Energy Information Administration, 2017). Planning for long-term sustainable nuclear power in the United States requires evaluation of both identified and potential undiscovered resources. Identified resources can provide uranium for short-term requirements, whereas undiscovered uranium resources are those that, if discovered and economically viable, satisfy long-term requirements.

In 2015, the U.S. Geological Survey (USGS) became aware of two previously unreported calcrete uranium deposits identified in the Southern High Plains region (fig. 1). These near-surface deposits of uranium-vanadate minerals are hosted in Pliocene and Pleistocene carbonate-rich ("calcrete") sediments. Surficial calcrete uranium deposits occur in arid regions of Australia, Namibia, and other countries but have not been reported in the United States until now (International Atomic Energy Agency, 1984). The discovery of the two deposits and other exploration targets throughout the Southern High Plains warranted an assessment for additional deposits.

\section{Assessment Methodology}

The USGS three-part methodology (Singer and Menzie, 2010) was used to assess the Southern High Plains region for undiscovered calcrete uranium deposits and their contained resources. This methodology uses known uranium deposit locations and deposit resources in combination with associated geologic features to estimate numbers of undiscovered deposits and to identify regions that may host them.
The method includes (1) definition of geographic regions (tracts) that are permissive for the occurrence of deposits as guided by known deposits and a descriptive mineral deposit model, (2) probabilistic estimation of numbers of undiscovered deposits within each permissive tract, and (3) calculation of the probable amount of undiscovered uranium based on the estimated number of undiscovered deposits and grade-tonnage models derived from the worldwide population of similar calcrete uranium deposits. For more information about this methodology, see https://minerals.usgs. gov/global/\#methodology.

\section{Undiscovered Resource Summary}

The USGS resource assessment identified the entire Southern High Plains region as a permissive tract, a region that contains the minimum geological characteristics that would permit calcrete uranium deposits to form. This permissive

Table 1. Assessment results for identified and undiscovered uranium resources in calcrete uranium deposits within the Southern High Plains region of the United States.

$\left[\mathrm{N}_{\mathrm{known}}\right.$, number of known deposits in the tract that have identified resources; $\mathrm{N}_{\mathrm{und}}$, number of undiscovered deposits calculated using a regression equation (Singer and Menzie, 2010); $\mathrm{U}_{3} \mathrm{O}_{8}$, uranium oxide; lbs, pounds. The permissive tract area in square kilometers $\left(\mathrm{km}^{2}\right)$ is inclusive of the favorable and prospective areas. Identified and undiscovered uranium resources are estimated as in-place. See Singer and Menzie (2010) for an explanation of quantitative mineral resource assessment methods]

\begin{tabular}{|c|c|c|c|c|c|c|c|c|c|c|}
\hline \multirow[t]{2}{*}{ Tract name } & \multirow[t]{2}{*}{ Age } & \multirow[t]{2}{*}{ Sub-tract } & \multirow[t]{2}{*}{$\begin{array}{l}\text { Permissive } \\
\text { area }\left(\mathbf{k m}^{2}\right)\end{array}$} & \multirow[t]{2}{*}{$\mathbf{N}_{\text {known }}$} & \multirow[t]{2}{*}{$\mathbf{N}_{\text {und }}$} & \multicolumn{3}{|c|}{$\begin{array}{l}\text { Probability of at least the indicated amount } \\
\text { of undiscovered } \mathrm{U}_{3} \mathrm{O}_{8} \text { (lbs) }\end{array}$} & \multirow[t]{2}{*}{$\begin{array}{l}\text { Mean undiscovered } \mathrm{U}_{3} \mathrm{O}_{8} \\
\text { resources }(\mathrm{lbs})\end{array}$} & \multirow[t]{2}{*}{$\begin{array}{l}\text { Identified } \mathrm{U}_{3} \mathrm{O}_{8} \\
\text { resources (Ibs) }\end{array}$} \\
\hline & & & & & & 0.9 & 0.5 & 0.1 & & \\
\hline \multirow{2}{*}{$\begin{array}{l}\text { Southern High } \\
\quad \text { Plains }\end{array}$} & \multirow{2}{*}{$\begin{array}{l}\text { Pliocene-- } \\
\text { Pleistocene }\end{array}$} & North & 43,920 & 0 & 1.1 & 0 & $4,200,000$ & $26,500,000$ & $9,000,000$ & 0 \\
\hline & & South & 46,630 & 2 & 3.9 & $8,100,000$ & $26,500,000$ & $59,500,000$ & $30,900,000$ & $2,660,000$ \\
\hline & Totals & & 90,550 & 2 & 5.0 & & & & $39,900,000$ & $2,660,000$ \\
\hline
\end{tabular}


tract was divided into two separate assessment sub-tracts, a north and a south tract (fig. 1). The assessment team identified the south tract as the area with a higher probability for the occurrence of this deposit type based on (1) known deposits and exploration sites; (2) favorable groundwater geochemistry; and (3) hydrologic conditions that favor the formation of deposits, including a greater abundance of transmissive sands in the subsurface, a higher rate of groundwater recharge, and shallower depth to groundwater. Within the south tract, a prospective area of highest potential for hosting undiscovered deposits was delineated based on the conditions listed above, particularly the occurrence of identified deposits and exploration sites (fig. 1).

In total, two tracts in the Southern High Plains were calculated to contain a mean estimate of 39.9 million pounds of in-place undiscovered $\mathrm{U}_{3} \mathrm{O}_{8}$ (table 1) of the calcrete uranium type. The south tract has approximately 80 percent of the estimated undiscovered uranium resources (30.9 million pounds $\mathrm{U}_{3} \mathrm{O}_{8}$ ). For comparison, the two known deposits, Buzzard Draw and Sulphur Springs Draw (fig. 1), both located in the south tract, contain a combined total of 2.6 million pounds of $\mathrm{U}_{3} \mathrm{O}_{8}$ (Van Gosen and Hall, in press).

This study identified a new region of uranium resources potential in the United States that has drawn little attention - the Southern High Plains of northwestern Texas, eastern New Mexico, and western Oklahoma. The calcrete uranium deposits within this region have the advantage of shallow depth and soft host rock. These qualities are amenable to open-pit mining during a time in which uranium prices and other factors are favorable.

\section{Assessment Team and Acknowledgments}

USGS: Susan M. Hall, Mark J. Mihalasky, Bradley S. Van Gosen, and George N. Breit (retired). Texas Bureau of Economic Geology: Brent A. Elliott. Uranium Energy Corporation:

Clyde L. Yancey.

Thanks to Brian Shaffer (USGS)

for reviewing the manuscript, and thanks to John Wallis (Serrano IT Services) for drafting figures. Robert Zielinski (USGS retired) reviewed the manuscript and contributed to productive discussion about the regional deposit model.

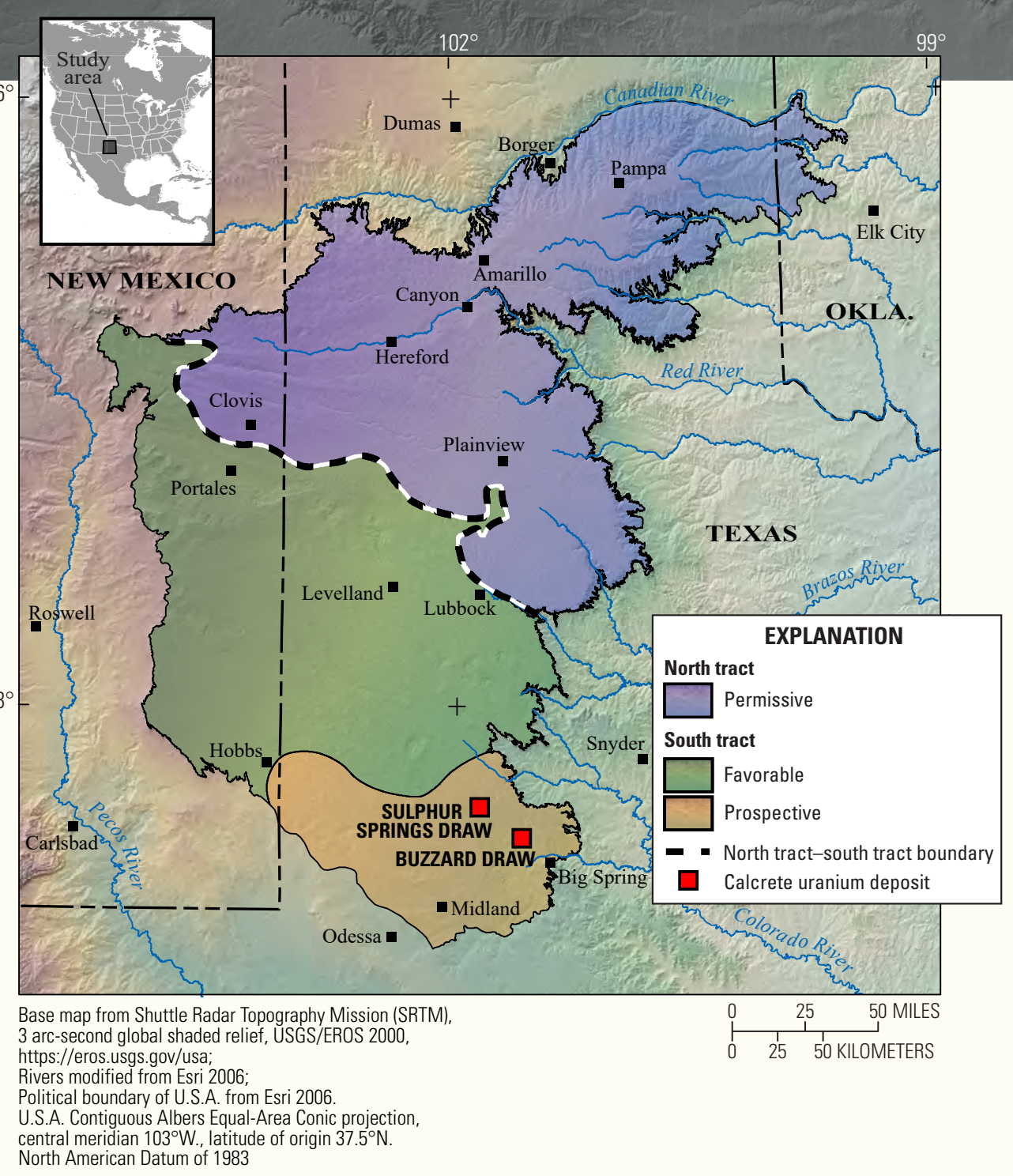

Figure 1. Mineral resource assessment tracts and two identified calcrete uranium deposits within the Southern High Plains region of the United States. The entire region has been designated as permissive for deposits with regions increasing from permissive to favorable and higher to prospective in the southern part of the tract.

\section{References Cited}

International Atomic Energy Agency, 1984, Surficial uranium deposits-Report of a working group on uranium geology: Vienna, Austria, International Atomic Energy Agency, IAEA-TECHDOC-322, 247 p.

Singer, D.A., and Menzie, W.D., 2010, Quantitative mineral resource assessments-An integrated approach: New York, Oxford University Press, 232 p.
U.S. Energy Information Administration, 2017, Uranium marketing annual report, June 19, 2017: U.S. Energy Information Administration, 71 p., accessed June 2017 at https://www.eia. gov/uranium/marketing/.

Van Gosen, B.S., and Hall, S.M., in press, The discovery and character of Pleistocene calcrete uranium deposits in the Southern High Plains of west Texas, United States: U.S. Geological Survey Scientific Investigations Report 2017-5134.

\section{Additional Information}

Susan M. Hall susanhall@usgs.gov (303) 236-1656
Bradley S. Van Gosen bvangose@usgs.gov (303) 236-1566 